\title{
Influence of soil type on half-highbush blueberry productivity
}

\author{
Tea Tasa, Marge Starast, Ele Vool, Ulvi Moor and Kadri Karp \\ Estonian University of Life Sciences, Institute of Agricultural and Environmental Sciences, Kreutzwaldi 1, 51014 Tartu, Estonia \\ e-mail: tea.tasa@emu.ee
}

\begin{abstract}
The aim of the present study was to determine the influence of mineral and peat soil condition on the growth, yield and nutrient uptake of some half-highbush blueberry cultivars. The peat soil experimental site was located in a harvested (milled) peat field. Four half-highbush blueberry (Vaccinium spp.) cultivars (five- and six-year-old plants) were used in the experiment: 'Aino', 'Alvar', 'Arne', and 'Northblue'. Environmental conditions exercised a considerable influence on biological processes of half-highbush blueberry, at the same time, a genotype-based variation was observed. Cultivar 'Northblue' had a higher yield in mineral soil and 'Aino' had the highest yield in peat soil considering the average of two years. The peat soil condition in the harvested peat field provided a better supply of nutrients for blueberry bushes compared to mineral soil and this, in its turn, secured better growth and a higher yield of blueberry bushes.
\end{abstract}

Key words: Vaccinium, soil, peat, growth, yield, cultivar

\section{Introduction}

Blueberries are the most widely grown fruit crop in the USA and Canada. Today, blueberries are grown commercially also in South America, Australia, New Zealand, Asia, South Africa and Europe (Strik 2005, Prodorutti et al. 2007). Almost $10 \%$ of the world total blueberry cultivated area is located in Europe therefore Poland and Germany are more important producers (Delian et al. 2010). In North European countries such as Norway, Sweden, Finland and Estonia, the cultivation of blueberries is also being considered. Climate conditions of North Europe are suitable for the lowbush (Vaccinium angustifolium Ait.) and half-highbush blueberry (V. corumbosum $x$ V. angustifolium) cultivation (Bläsing 1989, Haffner and Vestrheim 1994, Paasisalo et al. 1994, Starast et al. 2007a).

Interspecific hybridization has been an important aspect in the development of commercial cultivars and many combinations of species have been crossed (Lyrene and Balhgton 1986). The lowbush blueberry habitat is considered dominant when hybrids between highbush ( $V$. corymbosum L.) and lowbush blueberry genotypes occur (Finn and Luby 1986). This hybrid is named half-highbush blueberry and it is particularly cold hardy, having inherited the ability to survive the harsh winters of northern areas (Luby et al. 1986). They are most suitable for small-scale commercial cultivation in cold areas. One of their advantages is that they have inherited medium-sized, more easily picked fruit from the highbush blueberry while retaining the ability to rest undamaged under thick blankets of snow, which comes from their lowbush parentage. For the first time half-highbush blueberry breeding was developed at the University of Minnesota and the cultivar 'Northblue' has obtained a wide-spread popularity, for example in China (Xie and Wu 2009), Italy (Eccher et al. 2006), Latvia (Šterne and Ābolinš 2009), Finland (Lehmushovi and Hiirsalmi 1995) and Estonia (Starast et al. 2002). In Finland, in the MTT Agrifood Research Finland, Plant Production Research, Horticulture there have been bred several blueberry cultivars like 'Arne', 'Aino', 'Alvar', 'Hele', 'Tumma', 'Siro', 'Sine' (Lehmushovi 1998; Ylämäki and Tahvonen 2004). Other Vaccinium species were also used for crossing: 'Aron' and 'Arto' were created by the bog blueberry ( $V$. uliginosum) and for 'Tumma' $V$. brittonii was used (Lehmushovi 1998; Tahvonen et al. 2008). All these cultivars have good winter hardiness and some of these have very good resistance to Fusicoccus putrefaciens.

A blueberry plant needs acidic, well-aerated, sandy-textured soil high in organic matter for growth (Korcak 1988). Blueberries are calcifuges and typically found on podzolic soils that are considered infertile to other crops (Sanderson et al. 1996) with soil pH in the vicinity of 4.0 to 5.5 (Hall et al. 1964). Several studies have shown that peat application, like mulch or soil amendment before planting, increase plant productivity (Spiers 1986, Starast et al. 2002, Li et al. 2006, Ochmian et al. 2006, Xie and Wu 2009, Ancu et al. 2010). Peat is a very acidic organic material that improves soil condition and therefore influences significantly leaf photosynthesis, nutrient uptake, root activity, and mycorrhizal infection of blueberry plants. Berry quality is also affected by soils or substrates (Grajkowski et al. 2007, Starast et al. 2007a). 
In Estonia half-highbush blueberry is successfully cultivated in mineral soils (Starast et al. 2002, Starast et al. 2007a), lowbush blueberry has shown high productivity in peat soil (Vahejõe et al. 2010, Paal et al. 2011). Estonia is very rich in mires (Orru 1995) and peat production is a well-developed industry here. Peat is available and relatively inexpensive. At present there are thousands of hectares of harvested peat areas out of use in Estonia in the fields where the residue peat layer is rather thick because the peat harvest has been stopped due to the high water level.

In scientific studies more attention has been paid to highbush and lowbush blueberry. We turned our attention to half-highbush blueberry, raising a hypothesis that productivity of this blueberry taxon is affected by soil conditions. The aim of the present study was to determine the influence of mineral and peat soil condition on the growth, yield and nutrient uptake of some half-highbush blueberry cultivars.

\section{Material and methods}

\section{Experimental sites and plant material}

The blueberry experiments were established in mineral and peat soils. The experimental area of mineral soil was located in Tartu County $\left(58^{\circ} 20^{\prime} \mathrm{N}\right.$ and $\left.26^{\circ} 13^{\prime} \mathrm{E}\right)$, South Estonia and the study area was surrounded by production fields of horticultural crops. The peat soil experimental site was located in a harvested (milled) peat field, Tartu County $\left(58^{\circ} 13^{\prime} \mathrm{N}\right.$ and $26^{\circ} 7^{\prime} \mathrm{E}$ ), South Estonia; the peat field was bordered by a bog forest. The soil types in the experimental areas were the following: 1) mineral soil Haplic Stagnosol (Word Reference Base for Soil Resources 2006) sandy loam texture, 24-30 cm thick plough layer; 2) peat soil Fibric Histosol (Dystric, Drainic) (Word Reference Base for Soil Resources 2006), peat layer more than $1 \mathrm{~m}$ thick.

Experimental plants were planted in spring 2003. Four half-highbush blueberry (Vaccinium spp.) cultivars were used in the trial:

- 'Aino' ['Rancocas' x (V. uliginosum x 'Rancocas')] x V. angustifolium 'Augusta' (Lehmushovi 2000);

- 'Alvar' V. angustifolium 'Brunswick' x 'June' (Lehmushovi 2000);

- 'Arne' ['Rancocas' x (V. uliginosum x 'Rancocas')] (Lehmushovi 1998);

- 'Northblue' B-10 (G-65 x 'Ashworth') x US-3 ('Dixi' x Michigan Lowbush No. 1) (Luby et al. 1986).

Plantations were established in flat area with two-year-old micropropagated plants. The space between the rows was $2.5 \mathrm{~m}$ and plant-to-plant spacing was $1.0 \mathrm{~m}$. The experimental design was a randomized complete block with four replications and 10 plants per plot. Experimental plots were not irrigated. For this paper data were collected in 2006 (five-year-old plants - beginning of mature stage) and 2007(six-year-old plants - mature stage).

\section{Fertilizers and fertilization rates}

The quantities of the fertilizers were calculated according to the soil type, fertility (Table 1) and suggestions have been worked out by Finnish researchers Lehmushovi and Ylämäki (1999). Annual fertilizer application rates in different treatments were the following:

mineral soil complete fertilizer [nitrogen (N) $6 \%$, phosphorus (P) $5 \%$, potassium (K) $21 \%$, sulphur (S) $1.8 \%$, magnesium (Mg) $1.4 \%$, iron (Fe) $0.2 \%$, boron (B) $0.02 \%$, copper (Cu) $0.01 \%$, manganese (Mn) $0.1 \%$, zinc (Zn) $0.01 \%$, molybdenum (Mo) $0.002 \%$, cobalt (Co) $0.001 \%$, iodine $(\mathrm{J}) 0.001 \%$, chromium (Cr) $0.001 \%$ ] was applied in spring (May, June). Plants were fertigated three times with $0.5 \%$ solution every spring, total rate of fertilizer was $30 \mathrm{~kg}$ $\mathrm{ha}^{-1}$ (N $2 \mathrm{~kg} \mathrm{ha}^{-1}$, P $2 \mathrm{~kg} \mathrm{ha}^{-1}, \mathrm{~K} 6 \mathrm{~kg} \mathrm{ha}^{-1}$ )

peat soil complete fertilizer (N 10\%, P 4\%, K 17\%, Mg 2\%, S 11\%, B 0.2\%, Cu 0.01\%, Fe 0.1\%, Mn 0.7\%, Mo 0.01\%, Zn $0.1 \%$, Se $0.001 \%$ ) was applied once every spring (May). The fertilization (top dressing) rate was $400 \mathrm{~kg} \mathrm{ha}^{-1}(\mathrm{~N}$ $40 \mathrm{~kg} \mathrm{ha}^{-1}$, P $16 \mathrm{~kg} \mathrm{ha}^{-1}$, K $\left.68 \mathrm{~kg} \mathrm{ha}^{-1}\right)$. 
Table 1. Soil analyses data before establishing of experiments in 2002.

\begin{tabular}{lllllll}
\hline & \multicolumn{3}{c}{ Mineral element content, $\mathrm{mg} \mathrm{kg}^{-1}$} & \multicolumn{2}{c}{ Organic } \\
Soil type & $\mathrm{pH}_{\mathrm{KCl}}$ & $\mathrm{P}$ & $\mathrm{K}$ & $\mathrm{Ca}$ & $\mathrm{Mg}$ & matter, \% \\
\hline Mineral soil & 5.3 & 32 & 168 & 750 & 102 & 2.3 \\
Peat soil & 2.6 & 97 & 203 & 1049 & 372 & 85 \\
\hline
\end{tabular}

\section{Measuring of plant yield and growth}

Yield from each plant was harvested separately. The yield was picked in August (weekly, three times) 2006 and 2007. Total yield per bush was calculated. At the same time berry weight was determined. To find the berry weight (g), 10 berries in four replications were picked, weighed and the average was calculated. In 2007 the berry length $(\mathrm{cm})$ (from stem to calyx end) and berry diameter $(\mathrm{cm})$ (from side to side) of 10 berries in four replications were measured with a digital caliper.

During the harvesting time $(2006,2007)$ the leaf blade length $(\mathrm{mm})$, width $(\mathrm{mm})$ and surface area $\left(\mathrm{mm}^{2}\right)$ of 30 leafs in four replications were measured with a digital leaf area meter AM 100 (BioScientific Ltd).

At the end of the vegetation period (end of September in 2006, 2007) the width and height of the blueberry bushes was measured. The plant width was measured across and along the row and its average was calculated. The number of shoots (longer than $15 \mathrm{~cm}$ ) per plant was counted. Ten plants were measured in every replication.

Plants' winter damage was estimated at the beginning of vegetation period in May 2006 and 2007. A 9-point scale was used, where 1: no damage, 9: the whole plant was damaged (plant dieback to the soil level). In every replication ten plants were observed.

\section{Analyses of soil nutrient content and $\mathrm{pH}$}

Soil samples were taken prior to establishing the experiments in 2002 and in the autumn of 2007. Samples were taken close to the plants from the soil layer from the depth of $20 \mathrm{~cm}$. The $\mathrm{pH}$ was measured from the soil suspension with $1 \mathrm{M} \mathrm{KCl}(1: 5 \mathrm{w} / \mathrm{v})$ using the Evikon $\mathrm{pH}$ meter. The content of phosphorus (P) (ammonium lactate extractable), potassium ( $\mathrm{K}$ ) (ammonium lactate extractable), calcium ( $\mathrm{Ca}$ ) and magnesium $(\mathrm{Mg})$ (1 M ammonium acetate extract, $\mathrm{pH}$ 7.0) was determined (AOAC 1990). Organic matter concentration (\%) in soil was also analysed by loss on ignition. Three soil samples (replications) were analysed in every variant, one sample consisting of ten subsamples.

\section{Chlorophyll meter SPAD-500 measurements and leaf nutrient content}

The amount of chlorophyll content, a key indicator of plant health was evaluated using the portable chlorophyll meter SPAD-500 (Minolta Camera Co., Ltd. Japan). There are a strong correlation between SPAD measurements and leaf $\mathrm{N}$ content, thereby this meter is used for fast testing of leaf nitrogen content. Leaves of the same age and position (from the middle part of one-year-old, not fruit bearing shoots) on the plant were used; young leaves with non-uniform colour were left aside. Each reading consisted of measurements from 10 different plants and one sample consisted of 30 leaf measurements on the average. SPAD readings were measured at harvesting time in August 2006 and 2007 and at flowering time in May 2007.

The nutrient (nitrogen $\mathrm{N} \%$, phosphorus $\mathrm{P} \%$, potassium $\mathrm{K} \%$, calcium $\mathrm{Ca} \%$, and magnesium $\mathrm{Mg} \%$ ) content in the blueberry leaves was determined in the Laboratory of Plant Biochemistry at the Estonian University of Life Sciences. Leaf samples were collected at harvest in 2007. $\mathrm{N}$ concentration of air-dried samples was determined by the Kjeldahl method. The method involves the digestion of a sample in sulphuric acid using the Kjeldahl Cu catalyst to convert the protein nitrogen to ammonium sulphate. Ammonia is liberated by alkaline distillation using an automatic analyser Kjeltec Auto 1030. P, Ca, and Mg concentrations were measured by Kjeldahl digest using the flow injection analyser "FIAstar 5000". K concentration was determined flamephotometerically by an air-acetylene flame. P was determined at the wavelength $720 \mathrm{~nm}$ by the Stannous Chloride method and $\mathrm{Ca}$ at the wavelength $570 \mathrm{~nm}$ using o-Cresolphthalein Complexone, 8-Hydroxyquinoline to mark magnesium and 2-amino-2-methyl- 
propanol-1 as a buffer. Mg was determined by Titan Yellow at the wavelength $540 \mathrm{~nm}$. All nutrient concentrations were expressed on a dry weight basis (\% DW). Four samples replications in every variant were analysed and one sample consisted of leaves from ten plants.

\section{Statistical analysis}

Analysis of variance (two-way ANOVA) was used to compare all significant differences between soil types and halfhighbush blueberry cultivars. Average (mean) values of four cultivars depending on soil type (mineral soil, peat soil) and average influence of soil types are showed on figures and tables. Different letters indicate significant $(p<0.05)$ difference between cultivars in one experimental soil, besides a,b,c... for the 2006, A,B,C... for the 2007. By asterisk* is showed significant $(p<0.05)$ effect of the soil type on the cultivar. NS is marking non-significant effect of the soil type on the cultivar. By bold is showed significant $(p<0.05)$ influence of soil type.

\section{Results}

\section{Winter damages}

In 2006 winter damage was higher on 'Alvar' 6.3 points and 'Northblue' 5.3 points in mineral soil (Fig. 1). Less damage was indicated on cultivars 'Aino' and 'Arne'. In the same year in peat soil 'Northblue' had the least winter injury but 'Arne' ( 7.3 points) and 'Alvar' ( 7.0 points) had the highest. In the next experimental year the results showed less winter damage of all half-high cultivars in mineral soil. Cultivars 'Aino' and 'Northblue' had the highest damages compared to others. In peat soil 'Arne' (7.9 points) was the most damaged cultivar and 'Northblue' ( 2.9 points) and 'Aino' ( 2.8 points) were the least damaged. On an average the blueberry plants were more damaged in peat soil condition compared to mineral soil.

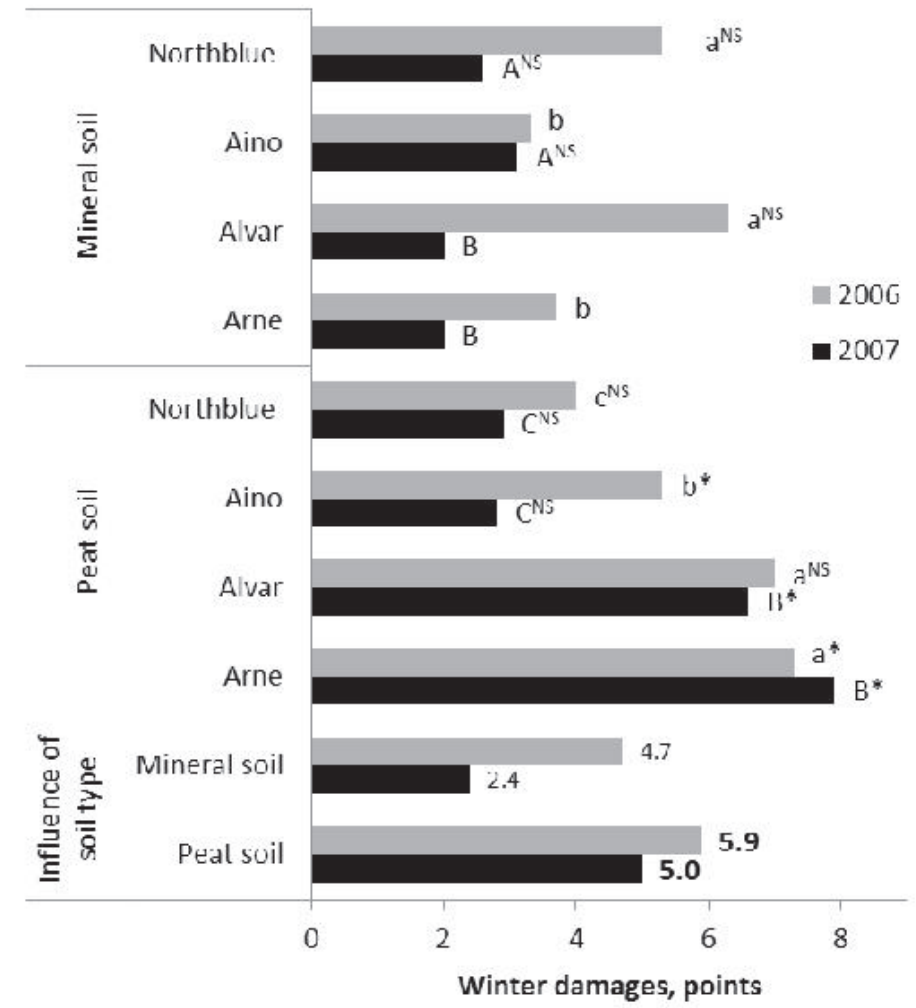

Fig.1. Winter damages (points) of four halfhighbush blueberry cultivars growing on mineral and peat soil in 2006 and 2007.

Mean values for each soil type followed by the same letter are not significantly different at $p<0.05$, besides $a, b, c$ for the year 2006, A,B,C for the year 2007.

* significant $(p<0.05)$ effect of the soil type on the cultivar, NS non-significant effect of the soil type on the cultivar.

Bold significant $(p<0.05)$ influence of soil type 


\section{Plant growth}

The five-year-old plant height was from 40.2 to $54.7 \mathrm{~cm}$ in mineral soil and from 53.9 to $79.3 \mathrm{~cm}$ in peat soil (Table 2). Cultivars 'Aino' and 'Northblue' had the lowest plants in mineral soil and 'Arne' had the highest plants. In peat soil cultivar 'Arne' plants were again the highest as opposed to cultivar 'Northblue' which had the lowest plants. In the second experimental year 'Arne' had the highest plants at both experimental sites. Cultivar 'Northblue' showed lowest growth both in mineral and in peat soil plantation.

Bush width (2006) varied from 48.1 to $52.1 \mathrm{~cm}$ in mineral soil and from 68.9 to $96.7 \mathrm{~cm}$ in peat soil (Table 2). In both experimental years cultivar 'Northblue' had significantly the smallest plant width in peat soil plantation. In 2007 the plants of 'Alvar' were the widest at the same experimental site. In mineral soil cultivar 'Aino' had the widest and 'Northblue' had the narrowest plant width.

Shoot developing was better for 'Northblue' and 'Aino' in mineral soil (Table 2). In peat soil cultivar 'Arne' had the lowest number of shoots compared to 'Northblue' and 'Alvar'. In 2007 developing of shoots was the best for 'Aino', whereas 'Alvar' had the lowest number of shoots. In peat soil experiment 'Northblue' and 'Alvar' had more shoots than other two cultivars.

Influence of soil types showed significant positive effect on plant growth parameters (Table 2). Only in 2007 there was no effect on height of cultivars 'Northblue' and 'Arne'.

Table 2. Plant growth parameters of four half-highbush blueberry cultivars growing on mineral and peat soil in 2006 and 2007.

\begin{tabular}{|c|c|c|c|c|c|c|c|}
\hline \multirow{2}{*}{ Soil type/Cultiva } & & \multicolumn{2}{|c|}{ Height, cm } & \multicolumn{2}{|c|}{ Width, cm } & \multicolumn{2}{|c|}{ Number of shoots } \\
\hline & & 2006 & 2007 & 2006 & 2007 & 2006 & 2007 \\
\hline \multirow{4}{*}{ Mineral soil } & Northblue & $40.2 c$ & $45.9 C^{N S}$ & $48.8 a$ & $50.7 \mathrm{D}$ & $4.6 a$ & $5.3 \mathrm{~B}$ \\
\hline & Aino & $42.4 c$ & $47.1 B C$ & $50.2 a$ & $60.0 \mathrm{~A}$ & $6.3 a$ & $10.0 \mathrm{~A}$ \\
\hline & Alvar & $50.0 \mathrm{~b}$ & $52.5 B$ & $52.1 a$ & $57.9 B$ & $3.9 b$ & $3.3 \mathrm{C}$ \\
\hline & Arne & $54.7 a$ & $66.9 A^{\mathrm{NS}}$ & $48.1 \mathrm{a}$ & $52.9 \mathrm{C}$ & $4.4 b$ & $5.3 \mathrm{~B}$ \\
\hline \multirow{4}{*}{ Peat soil } & Northblue & $53.9 c^{*}$ & $48.1 C^{N S}$ & $68.9 b^{*}$ & $84.2 C^{*}$ & $24.1 a^{*}$ & $26.3^{*} \mathrm{~A}$ \\
\hline & Aino & $60.6 b^{*}$ & $59.6 B^{*}$ & $96.7 a^{*}$ & $98.0 B^{*}$ & $19.6 a b^{*}$ & $20.9 * B$ \\
\hline & Alvar & $63.4 b^{*}$ & $62.7 B^{*}$ & $88.6 a^{*}$ & $106.6 A^{*}$ & $23.0 a^{*}$ & $25.7 A^{*}$ \\
\hline & Arne & 79.3a* & $69.0 A^{\mathrm{NS}}$ & 91.7a* & $98.2 \mathrm{~B}^{*}$ & $18.0 b^{*}$ & 19.3B* \\
\hline \multirow{2}{*}{$\begin{array}{l}\text { Influence of } \\
\text { soil type }\end{array}$} & Mineral soil & 46.8 & 53.1 & 49.8 & 55.4 & 4.8 & 6.0 \\
\hline & Peat soil & 64.3 & 59.8 & 86.4 & 96.7 & 21.2 & 23.0 \\
\hline
\end{tabular}

Mean within columns (for each soil type) followed by the same letter are not significantly different at $p<0.05$, besides a,b,c... for the 2006 , A,B,C... for the 2007 .

* significant $(p<0.05)$ effect of the soil type on the cultivar, NS non-significant effect of the soil type on the cultivar.

Bold significant $(p<0.05)$ influence of soil type

In the first experimental year (2006) the blueberry leaf length varied from 41.4 to 58.8 in mineral soil and from 54.0 to 69.2 in peat soil (Table 3). Cultivars 'Arne' and 'Northblue' had longer leaves than 'Aino' and 'Alvar' in mineral soil experimental site. In peat soil 'Arne' had longer leaves and cultivar 'Aino' had shorter leaves. Next year at both experimental sites 'Arne' showed longer leaves than other cultivars.

Study years showed that the leaf blade width was bigger for cultivars 'Northblue' and 'Arne' in mineral soil (Table 3). Otherwise 'Aino' had the narrowest leaf compared to other cultivars. In peat soil cultivar 'Aino' had the narrowest leaf but only 'Arne' demonstrated the widest leaf in both years.

Leaf surface area was between 554.5 and $1041.4 \mathrm{~mm}^{2}$ in mineral soil (Table 3). Cultivar 'Northblue' had the largest leaf followed by 'Arne', 'Alvar', 'Aino' respectively. Quite a similar trend was observed in 2007, though between cultivars 'Northblue' and 'Arne' there was no significant difference. In peat soil 'Arne' had the largest and cultivar 'Aino' had the smallest leaf. Both experimental years indicated that in mineral soil all cultivars had smaller leaves than in peat. It is affirmed by leaf length, width and surface area. 
Table 3. Leaf parameters of four half-highbush blueberry cultivars growing on mineral and peat soil in 2006 and 2007.

\begin{tabular}{|c|c|c|c|c|c|c|c|}
\hline \multirow{2}{*}{ Soil type/Cultivar } & & \multicolumn{2}{|c|}{ Length, $\mathrm{mm}$} & \multicolumn{2}{|c|}{ Width, mm } & \multicolumn{2}{|l|}{ Area, $\mathrm{mm}^{2}$} \\
\hline & & 2006 & 2007 & 2006 & 2007 & 2006 & 2007 \\
\hline \multirow{4}{*}{ Mineral soil } & Northblue & $58.8 a$ & $52.3 \mathrm{~A}$ & $26.8 a^{N S}$ & $25.2 A^{N S}$ & $1041.4 a^{N S}$ & $914.5 A$ \\
\hline & Aino & $41.4 b$ & $43.1 B$ & $20.1 c$ & $19.8 \mathrm{~B}$ & $554.5 d$ & $605.4 \mathrm{C}$ \\
\hline & Alvar & $43.9 b$ & $46.4 \mathrm{AB}$ & $22.8 b$ & $25.0 \mathrm{~A}$ & $664.4 c$ & $800.8 \mathrm{~B}$ \\
\hline & Arne & $56.2 a$ & $52.5 \mathrm{~A}$ & $26.7 a$ & $25.4 \mathrm{~A}$ & $995.8 b$ & $927.5 \mathrm{~A}$ \\
\hline \multirow{4}{*}{ Peat soil } & Northblue & $62.6 b^{*}$ & $59.4 B^{*}$ & $27.6 b^{N S}$ & $27.0 \mathrm{~B}^{\mathrm{NS}}$ & $1138.9 c^{\mathrm{NS}}$ & $1042.4 B^{*}$ \\
\hline & Aino & $54.0 c^{*}$ & $55.2 \mathrm{BC}^{*}$ & $26.2 c^{*}$ & $25.5 C^{*}$ & $937.2 d^{*}$ & $925.5 D^{*}$ \\
\hline & Alvar & $59.2 b *$ & $52.2 C^{*}$ & $32.3 a^{*}$ & $28.1 B^{*}$ & $1260.0 b^{*}$ & $964.4 C^{*}$ \\
\hline & Arne & $69.2 a^{*}$ & $75.0 A^{*}$ & $32.2 a^{*}$ & $36.1 A^{*}$ & 1477.0a* & 1844.0A* \\
\hline \multirow{2}{*}{$\begin{array}{l}\text { Influence of soil } \\
\text { type }\end{array}$} & Mineral soil & 50.1 & 48.6 & 24.1 & 23.8 & 814.0 & 812.0 \\
\hline & Peat soil & 61.3 & 60.4 & 29.6 & 29.2 & 1203.3 & 1194.1 \\
\hline
\end{tabular}

Mean within columns (for each soil type) followed by the same letter are not significantly different at $p<0.05$, besides a,b,c for the 2006 , A,B,C for the 2007 .

* significant $(p<0.05)$ effect of the soil type on the cultivar, NS non-significant effect of the soil type on the cultivar.

Bold significant $(p<0.05)$ influence of soil type

\section{Plant yield and berry parameters}

In the first crop year (2006) the a total yield varied between $8.3 \mathrm{~g}$ ('Arne') and $133.6 \mathrm{~g}$ ('Northblue') per plant in mineral soil and $9.3 \mathrm{~g}$ ('Northblue') and 472.2 g ('Aino') in peat soil (Table 4). In 2007 cultivar 'Aino' had the highest yield in mineral soil and cultivar 'Arne' had the lowest yield. In peat soil 'Northblue' had a very poor productivity in experimental years. The highest yield from one plant was harvested from 'Aino'.

Berry parameters varied in a rather large range depending on the experimental site, year and cultivar. The twoyear data showed that cultivar 'Northblue' had heavier and 'Arne' had lightweight berries in mineral soil (Table 4). In peat soil 'Arne' had the heaviest berries compared to others in 2006 . However, in 2007 cultivar 'Northblue' had heavier berries than 'Arne' and other cultivars. At the same time the length and diameter of the berries did not vary largely and there were no significant differences between cultivars. In mineral soil the berry length ranged from 0.9 to $1.1 \mathrm{~cm}$ and the diameter from 1.2 to $1.5 \mathrm{~cm}$. On an average the soil types had no effect on berry length and diameter.

Table 4. Plant yield and berry parameters of four half-highbush blueberry cultivars growing on mineral and peat soil in 2006 and 2007.

\begin{tabular}{|c|c|c|c|c|c|c|c|}
\hline \multirow[t]{2}{*}{ Soil type/Cultivar } & & \multicolumn{2}{|l|}{$\begin{array}{l}\text { Yield, } \\
\text { g plant }^{-1}\end{array}$} & $\begin{array}{l}\text { Berry } \\
\text { Weight, } \\
\text { g }\end{array}$ & & $\begin{array}{l}\text { Length, } \\
\mathrm{cm}\end{array}$ & $\begin{array}{l}\text { Diameter, } \\
\mathrm{cm}\end{array}$ \\
\hline & & 2006 & 2007 & 2006 & 2007 & 2007 & 2007 \\
\hline \multirow{4}{*}{ Mineral soil } & Northblue & 133.6a* & $68.4 C^{*}$ & $1.5 a^{*}$ & $0.9 \mathrm{~A}$ & $1.0 \mathrm{AB}^{\mathrm{NS}}$ & $1.5 A^{\mathrm{NS}}$ \\
\hline & Aino & $59.1 c$ & $360.3 \mathrm{~A}$ & $0.9 b c$ & $0.7 \mathrm{AB}$ & $0.9 \mathrm{~B}^{\mathrm{NS}}$ & $1.2 \mathrm{~B}$ \\
\hline & Alvar & $72.5 b$ & $301.9 \mathrm{~B}$ & $1.0 \mathrm{~b}$ & $0.5 \mathrm{BC}$ & $1.1 \mathrm{~A}^{\mathrm{NS}}$ & $1.2 \mathrm{~B}$ \\
\hline & Arne & $8.3 d^{*}$ & $10.3 \mathrm{D}$ & $0.8 c$ & $0.4 \mathrm{C}$ & $0.9 \mathrm{~B}^{\mathrm{NS}}$ & $1.2 \mathrm{~B}$ \\
\hline \multirow{4}{*}{ Peat soil } & Northblue & $9.3 d$ & $5.9 \mathrm{D}$ & $1.3 b$ & $2.2 A^{*}$ & $1.0 \mathrm{~A}^{\mathrm{NS}}$ & $1.4 \mathrm{~A}^{\mathrm{NS}}$ \\
\hline & Aino & $475.2 a^{*}$ & $651.3 A^{*}$ & $1.2 b^{*}$ & $1.0 C^{*}$ & $1.0 \mathrm{~A}^{\mathrm{NS}}$ & $1.4 A^{*}$ \\
\hline & Alvar & $148.2 b^{*}$ & 107.0B* & $1.3 b^{*}$ & $1.1 \mathrm{C}^{*}$ & $1.1 \mathrm{~A}^{\mathrm{NS}}$ & $1.4 A^{*}$ \\
\hline & Arne & $41.5 c$ & $71.4 C^{*}$ & $1.6 a^{*}$ & $1.7 \mathrm{~B}^{*}$ & $1.0 \mathrm{~A}^{\mathrm{NS}}$ & $1.5 A^{*}$ \\
\hline \multirow{2}{*}{$\begin{array}{l}\text { Influence of soil } \\
\text { type }\end{array}$} & Mineral soil & 68.4 & 185.2 & 1.0 & 0.6 & 1.0 & 1.3 \\
\hline & Peat soil & 168.6 & 208.9 & 1.4 & 1.5 & 1.1 & 1.4 \\
\hline
\end{tabular}

Mean within columns (for each soil type) followed by the same letter are not significantly different at $p<0.05$, besides $a, b, c$ for the 2006, $A, B, C$ for the 2007.

${ }^{*}$ significant $(p<0.05)$ effect of the soil type on the cultivar, NS non-significant effect of the soil type on the cultivar. Bold significant $(p<0.05)$ influence of soil type 


\section{Soil nutrient content and $\mathrm{pH}$}

Analyses of soils showed that nutrient (P, K, Ca, Mg) content was on a low level before planting (Table 1). After four years extractable phosphorus, potassium, and magnesium content was higher in peat compared to mineral soil (Table 5). Considering different soil types and average plant growth requirement characteristics, phosphorus and potassium content in both experimental soils was high, moreover, magnesium content was very high in peat soil. Inversely, calcium content was low. Changes in nutrient content were induced by fertilization as well natural processes in different soils with plant partnership. Mineral soil acidity was lower compared to peat soil (Table 5). Organic matter content was clearly higher in peat soil, however the organic matter content had decreased by $12 \%$ compared to the same parameter taken prior to establishing the experiments in 2002 (Table 1).

Table 5. Data of soil analyses of two experimental areas in 2007.

\begin{tabular}{lllllll}
\hline & \multicolumn{4}{c}{ Mineral element content, $\mathrm{mg} \mathrm{kg}^{-1}$} & & \multicolumn{2}{c}{ Organic } \\
Soil type & $\mathrm{pH}_{\mathrm{KCl}}$ & $\mathrm{P}$ & $\mathrm{K}$ & $\mathrm{Ca}$ & $\mathrm{Mg}$ & $\mathrm{matter} \%$ \\
\hline Mineral soil & $4.8 \mathrm{~A}$ & $129.9 \mathrm{~B}$ & $274.3 \mathrm{~B}$ & $784 \mathrm{~A}$ & $117.6 \mathrm{~B}$ & $3.0 \mathrm{~B}$ \\
Peat soil & $2.2 \mathrm{~B}$ & $202.63 \mathrm{~A}$ & $330.4 \mathrm{~A}$ & $605.3 \mathrm{~B}$ & $510.9 \mathrm{~A}$ & $72.5 \mathrm{~A}$ \\
\hline
\end{tabular}

Mean within columns followed by the same letter are not significantly different at $p<0.05$.

\section{SPAD-500 values and leaf nutrient content}

In the three-year old plantation (2006, mineral soil) the blueberry plant leaves of cultivars 'Northblue' and 'Arne' had higher SPAD chlorophyll meter value compared to 'Alvar' (Fig. 2). In peat soil 'Arne' had higher SPAD value compared to 'Aino' and 'Alvar'. All cultivars had a higher SPAD value in peat soil. In the second experimental year SPAD value was measured at flowering time in addition to harvesting time. Chlorophyll meter readings of mineral soil experimental site did not vary largely (Fig. 3). However, at flowering time there was a significant difference between cultivars 'Northblue' and 'Aino'. At harvesting time specifically 'Aino' had the highest SPAD value and 'Alvar' had the lowest value. In peat soil experiment SPAD reading ranged very largely, though all cultivars had a lower SPAD value at flowering time. Cultivar 'Arne' had a higher SPAD value compared to 'Northblue' and 'Aino' during both observation periods. SPAD value of flowering time was higher in mineral soil excluding cultivar 'Alvar'. In harvesting time peat soil increased the value significantly.

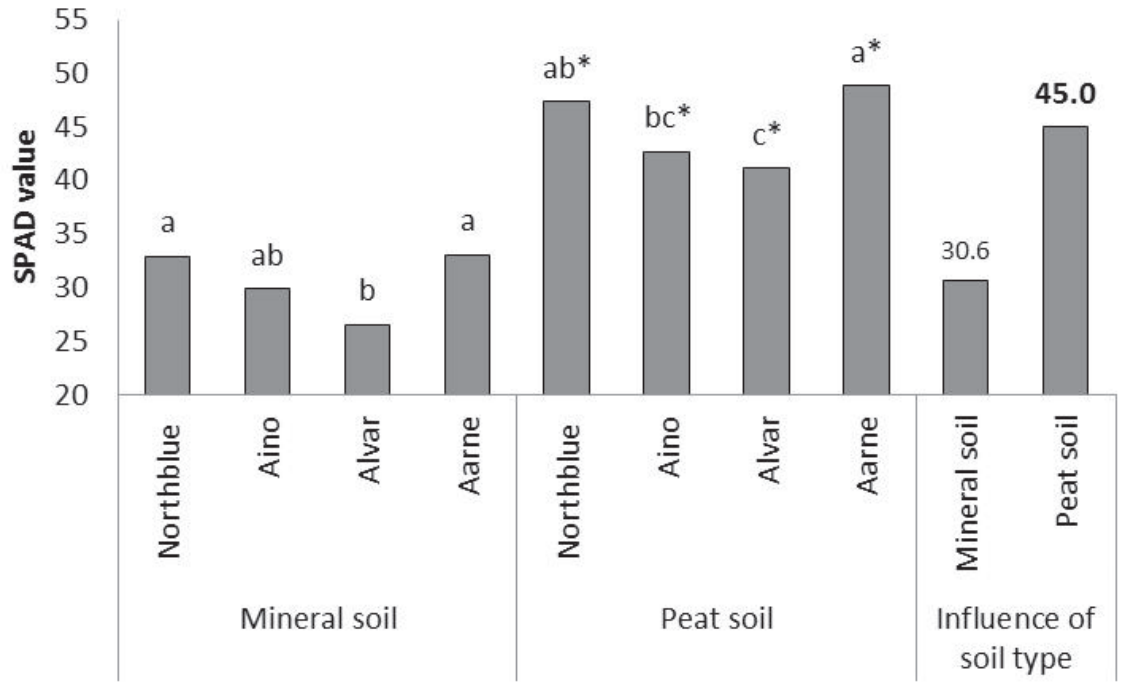

Mean values (for each soil type) followed by the same letter are not significantly different at $p<0.05$. * significant $(p<0.05)$ effect of the soil type on the cultivar, NS non-significant effect of the soil type on the cultivar.

Bold significant $(p<0.05)$ influence of soil type
Fig. 2. SPAD values of four half-highbush blueberry cultivars growing on mineral and peat soil at harvesting time in 2006. 


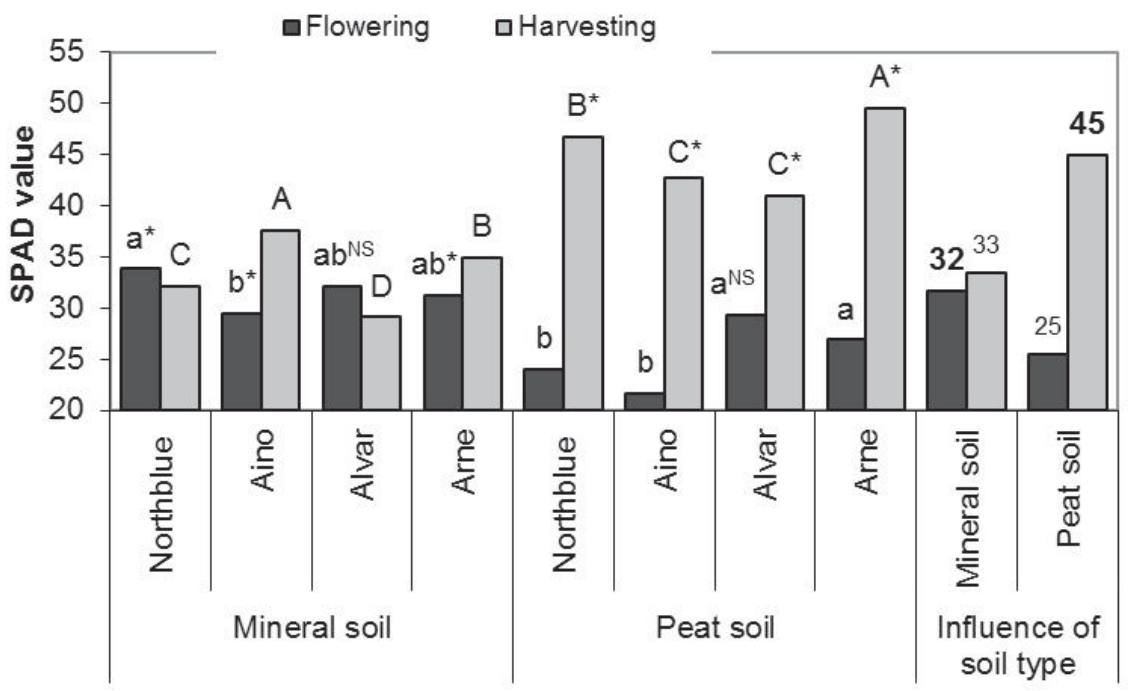

Fig. 3. SPAD values of four half-highbush blueberry cultivars growing on mineral and peat soil at flowering and harvesting time in 2007.

Mean values (for each soil type) followed by the same letter are not significantly different at $p<0.05$, besides $a, b, c$ for the flowering time, $A, B, C$ for the harvesting time.

* significant $(p<0.05)$ effect of the soil type on the cultivar, NS non-significant effect of the soil type on the cultivar.

Bold significant $(p<0.05)$ influence of soil type

Nitrogen content varied from 1.14 to $2.16 \%$ in experiments (Table 6). In mineral soil plantation cultivar 'Aino' had the lowest nitrogen content. Plants grown in peat soil condition had higher nitrogen level generally. The highest content of nitrogen was measured in cultivars 'Alvar' and 'Arne'. However, nitrogen content of 'Nortblue' was only $1.63 \%$. Phosphorus content was also higher in plants which were cultivated in peat soil. Variability between cultivars was not large but 'Aino' had the lowest phosphorus content in both experimental sites. In mineral soil plant leaves of 'Northblue' had the highest and cultivar 'Alvar' had the lowest concentration of potassium. 'Arne' had the highest potassium content followed by 'Alvar', 'Northblue' and 'Aino' in peat soil plantation. Calcium content in leaves was from 0.43 to $0.56 \%$ in mineral soil and from 0.41 to $0.50 \%$ in peat. In mineral soil leaves of 'Arne' had the highest level of calcium. Leaves of cultivars 'Arne' and 'Aino' contained much more calcium compared to 'Northblue' and 'Alvar' in peat soil. Magnesium concentration in leaves was between 0.18 and $0.24 \%$. In mineral soil higher content of magnesium was indicated in leaves of 'Northblue' and 'Arne' as opposed to cultivars 'Aino' and 'Alvar'. A similar trend did not appear in peat soil experiment, there cultivars 'Aino' and 'Arne' had a higher content of magnesium. On an average nitrogen and phosphorus content were the highest in leaves from peat soil.

Table 6. Leaf nutrient contents (\% DW) of four half-highbush blueberry cultivar growing on mineral and peat soil in 2007.

\begin{tabular}{|c|c|c|c|c|c|c|}
\hline \multirow{2}{*}{ Soil type/Cultivar } & & \multicolumn{5}{|c|}{ Mineral element content, \% } \\
\hline & & $\mathrm{N}$ & $\mathrm{P}$ & $\mathrm{K}$ & $\mathrm{Ca}$ & $\mathrm{Mg}$ \\
\hline \multirow{4}{*}{ Mineral soil } & Northblue & $1.27 \mathrm{~A}$ & $0.11 \mathrm{~A}$ & $0.51 A^{*}$ & $0.47 B^{*}$ & $0.22 A^{*}$ \\
\hline & Aino & $1.14 \mathrm{~B}$ & $0.09 B$ & $0.38 \mathrm{C}$ & $0.43 B$ & $0.19 B$ \\
\hline & Alvar & $1.29 \mathrm{~A}$ & $0.11 \mathrm{~A}$ & $0.36 \mathrm{D}$ & $0.48 \mathrm{~B}^{\mathrm{NS}}$ & $0.18 \mathrm{~B}^{\mathrm{NS}}$ \\
\hline & Arne & $1.27 \mathrm{~A}$ & $0.11 \mathrm{~A}$ & $0.48 \mathrm{~B}$ & $0.56 A^{*}$ & $0.21 \mathrm{~A}$ \\
\hline \multirow{4}{*}{ Peat soil } & Northblue & $1.63 C^{*}$ & $0.14 A^{*}$ & $0.45 \mathrm{C}$ & $0.41 B$ & $0.19 B$ \\
\hline & Aino & $1.85 \mathrm{~B}^{*}$ & $0.12 B^{*}$ & $0.44 C^{*}$ & $0.50 A^{*}$ & $0.24 A^{*}$ \\
\hline & Alvar & $2.14 A^{*}$ & $0.14 A^{*}$ & $0.48 B^{*}$ & $0.45 B^{\mathrm{NS}}$ & $0.19 \mathrm{~B}^{\mathrm{NS}}$ \\
\hline & Arne & $2.16 A^{*}$ & $0.14 A^{*}$ & $0.50 A^{*}$ & $0.50 \mathrm{~A}$ & $0.24 A^{*}$ \\
\hline \multirow{2}{*}{$\begin{array}{l}\text { Influence of soil } \\
\text { type }\end{array}$} & Mineral soil & 1.24 & 0.10 & 0.43 & 0.49 & 0.20 \\
\hline & Peat soil & 1.95 & 0.14 & 0.47 & 0.47 & 0.21 \\
\hline
\end{tabular}

Mean within columns (for each soil type) followed by the same letter are not significantly different at $p<0.05$.

* significant $(p<0.05)$ effect of the soil type on the cultivar, NS non-significant effect of the soil type on the cultivar.

Bold significant $(p<0.05)$ influence of soil type 


\section{Discussion}

In northern areas low temperature combined with insufficient cold hardiness are among the major factors limiting growth and productivity of introduced crop plants. The two-year study has shown that in mineral soil the cultivar 'Arne' was less damaged. In peat area, contrariwise, cultivar 'Arne' had more damages. Lehmushovi (1998) indicated that cultivar 'Arne' has been healthy and has wintered well in southern Finland. Data of our study showed that in mineral soil condition the blueberry plants wintered well but results were different in peat soil. Low-statured half-high cultivars can be also successful in cold climates because plants are frequently covered with snow which protects them against desiccation in mid-winter. In the winter of 2006, there was little precipitation (from 5 to $17 \mathrm{~mm}$ ) but in 2007 the snow cover was much thicker (EMHI 2006, 2007). Air temperatures were lower in 2006 as well. In the January temperature dropped to $-29^{\circ} \mathrm{C}$. Data from the mineral soil experiment gave a very clear indication of higher winter damages in the first study year (2006) which can be caused primarily by a low snow depth. Wildung and Sargent (1989) also proved that half-highbush blueberry plants did not have much winter damages when the snow depth was $15-30 \mathrm{~cm}$. In addition to low temperature extremes, plants can also be damaged by fluctuating temperatures. This problem appeared especially deeply in the winter of 2006 (EMHI 2006), increasing the winter damages of blueberry plants. This trend did not appear as clearly in peat soil. On the average, blueberries had more damages in peat soil. This might have been caused by the difference in microclimate compared to the mineral soil experiment. Brown (1976) has shown that perennial temperatures of clear-cut peat bogs vary considerably depending on vegetated peat or mineral soils. Clear-cut peat areas are located on lower levels (in the hollows), for this reason night frosts can appear in late summer or early autumn. This problem has emerged in other blueberry studies where early frosts have damaged new, not lignified blueberry shoots in autumn already (Vahejõe et al. 2010). In this referred study, young, in juvenile stage blueberry plants, had more damages compared to plants in a mature stage.

At both experimental sites the half-highbush blueberry cultivar 'Arne' had the highest bushes in all soils and study years. Lehmushovi (1998) mentioned that the characteristic plant height of 'Arne' ranged from 0.8 to $1.2 \mathrm{~m}$. In our experiment the blueberry plants were young and the mean height of the cultivar 'Arne' was lower -0.67 $\mathrm{m}$. Other cultivars had also lower bushes compared to the characteristics of Luby et al., (1986) and Lehmushovi (2000). In mineral soil measuring of the five-year-old plants showed no significant differences between cultivars but next year 'Aino' had the largest plants. In peat soil cultivar 'Alvar' had larger plants in 2006 and 2007. 'Alvar' has been characterised as a cultivar with very large plants -1.0-1.3 $\mathrm{m}$ (Lehmushovi 2000). In the second year, the plant width of 'Alvar' was also more than one meter $(1.07 \mathrm{~m})$ only at the peat soil experimental site. The number of shoots indicated that the trends differed in different soils and study years. In mineral soil the blueberry cultivar 'Aino' developed more shoots, concurrently 'Alvar' had a smaller number of shoots on the average. Cultivars 'Northblue' and 'Alvar' had more shoots and 'Arne' had less shoots in peat soil. All mentioned parameters demonstrated that plants cultivated in peat soil had a better growth compared to those in mineral soil. In addition, half-highbush blueberry plants grown in peat soil developed four times more shoots than those in mineral soil. The favourable effect of peat is mentioned also in other study where the half-highbush blueberry grew best when peat was used for ground mixture or as mulch (Starast et al. 2002). Compared to the control site (without peat), the plant growth was more than two times better while using peat.

As a result of two experimental years, a conclusion may be drawn that cultivar 'Arne' grew the longest and widest leaves compared to other cultivars. Bush growth parameters also demonstrate a powerful growth of this cultivar 'Arne'. Lehmussovi (1998) has described the leaf length of cultivar 'Arne'to be $4.04 \mathrm{~cm}$ and its leaf width to be $1.88 \mathrm{~cm}$. In our experiment this cultivar demonstrated higher leaf parameters both in mineral soil and peat soil. But the soil types had no effect on leaf width and area (2006) of cultivar 'Northblue'. It can be stated that on the average plants grown in peat soil had bigger leaves during our experiment. Xie and Wu (2009) indicated a positive effect of peat on the number of half-highbush blueberry leaves and the average leaf area compared to garden soil. In our experiment the leaf area was, on average, $47 \%$ larger than that of the plants grown in peat soil. A larger leaf area increased essentially the photosynthetic area of the plant, affecting other physiological processes which determine the whole productivity of a plant.

In the first experimental year (five-year-old plants) the yield, the size and weight of the berries of the cultivar 'Northblue' grown in mineral soil was the highest, but in the second experimental year such a tendency was not noted and in peat soil cultivar 'Northblue' was the one with lower yield in both experimental years. Earlier studies in Northern countries have indicated a high yield just of this cultivar (Starast et al. 2002, Šterne and Āboliňs 2009, Barney and Hummer 2011) but all these experiments have been made in mineral soil. Cultivar 'Aino' had a higher yield in both soils considering the average of two years. This cultivar has demonstrated a high and equiva- 
lent yield from plants of the same age also in Finland (Lehmushovi et al. 2000). In mineral soil cultivar 'Arne' demonstrated the lowest yield considering the average of two years. Lehmushovi (1998) has characterised the yield of this cultivar to be mostly 300-500 g per bush, in good years as much as $1 \mathrm{~kg}$ per bush. In our experiment the yield of 'Arne' did not reach even $100 \mathrm{~g}$ per bush. In Finland cultivar 'Alvar' has demonstrated even a higher yield than cultivar 'Aino' (Lehmushovi et al. 2000), whereas in our experiment this cultivar had a more modest yield. There appeared a trend that in case of high yield the berries were smaller. Still, cultivar 'Arne' had a very low yield and its berries were very small, especially in the mineral soil experiment. There did not appear any strong effect of cultivar on berry length and diameter at the peat soil experimental site. Considering the average of the experiment, the yield and the berry weight of the bushes grown in peat soil were considerably higher than that of the bushes grown in mineral soil. Presumably, the soil condition in peat was more favourable for the blueberry, securing a better assimilation of nutrients and promoting the initial vegetative growth of the bushes which, in its turn, produced a higher yield of these bushes.

While taking as a basis the optimum ranges of nutrients in leaves created by Trevett (1972), we can see that all the cultivars grown in mineral soil lacked $\mathrm{N}$ and $\mathrm{P}$. The concentration of these nutrients in the bushes grown in peat soil was higher and none of the cultivars demonstrated a level of leaf nutrients below the recommended range. The concentration of $\mathrm{P}$ in leaves was either below or at the threshold of the recommended range, though the concentration of this element in the soil was high. Potassium is an important element both in photosynthesis and water regulation and there is a principle: the higher the yield of the bushes, the lower is the concentration of $\mathrm{K}$ in leaves (Trevett 1972). Our experiment revealed the same tendency, especially in cultivar 'Aino', the yield of which was high at both experimental sites in the second year of our experiment (2007), while the concentration of $\mathrm{K}$ in the leaves was lower, though there was enough $\mathrm{K}$ in the soil. In addition to K deficit, cultivar 'Aino'appeared to have the deficit of $\mathrm{N}$ and $\mathrm{P}$.

As to $\mathrm{Ca}$ and $\mathrm{Mg}$, their concentration in plant leaves was within the optimum range at both experimental sites. At the same time, the concentration of $\mathrm{Ca}$ in the soil was rather low, but plants could assimilate this element very well. A low concentration of $\mathrm{Ca}$ in the soil does not always mean that the plant should lack this element, while the assimilation of $\mathrm{Ca}$ is significantly related to the level of $\mathrm{pH}$ in the soil (Spiers and Braswell 1992). In the present experiment, a better assimilation of Ca was observed in plants growing in mineral soil ( $\mathrm{pH} 4.8)$ compared to peat soil $(\mathrm{pH} 2.2)$.

In general, $\mathrm{pH}$ in the soil influences the assimilation of elements by blueberries and this plant species has adjusted itself to growing in acidic soil. In our experiment the $\mathrm{pH}$ level at both sites was suitable for blueberry and this could not have any significant effect on the supply of mineral elements for the plants. Blueberry bushes were fertilized at both experimental sites and the calculation of the respective norms was based on the blueberry physiological characteristics and the features of test soils. Nevertheless, statistical data processing indicated that the concentration of $\mathrm{N}$ and $\mathrm{P}$ in leaves was significantly influenced by the soil of the experimental site. The concentration of $\mathrm{N}$ in leaves remained rather low, therefore, while fertilizing the bushes, more attention should be paid to this element, especially in case of a mineral soil plantation. Due to the high concentration of organic matter, peat soil has a higher potential of plant nutrient supplies, especially in $\mathrm{N}$ supplies. $\mathrm{N}$ has also a significant influence on the assimilation of $\mathrm{P}$ by plants (Korcak 1988), the deficit of which was also noted in test bushes. The influence of soil was lower on the assimilation of $\mathrm{K}, \mathrm{Ca}$ and $\mathrm{Mg}$ in our experiment, a higher influence was exercised, first of all, by genotypic features. Korcak (1988) has underlined it in his review article that there is a wide variety of different nutrient needs among the Vaccinium species, varying also among the cultivars. The nutrient need of highbush (the second parent of half-highbush blueberry together with lowbush blueberry) is somewhat higher, but it varies considerably between the cultivars. No optimum nutrient levels have been described for half-highbush blueberry, but the referred study indicates that there is a considerable variety also among these cultivars.

SPAD value was higher in peat soil in the first experimental year at harvesting time (2006). In the second year of the experiment, the portable chlorophyll meter value was measured at flowering and harvesting time. At peat soil sites SPAD value was higher at harvesting time but this trend was not observed in mineral soil. There were significant variations also between cultivars. On the average, plant leaves had a higher SPAD value in peat compared to mineral soil. Chlorophyll meter value is strongly correlated with the nutrient status, especially nitrogen in blueberry plant leaf (Starast et al. 2007b). More chlorophyll is generated in the leaves of the plants which have assimilated more nutrients and this is directly demonstrated in the SPAD value. Starast et al. (2005) have indicated that mixing of peat in the mineral soil before the blueberry plants are planted and the application of peat mulch will significantly improve the nutrition conditions of plants and this was also illustrated by the increase of the chlorophyll meter value by 1.5 times. Moreover, the present study demonstrated that at peat soil test site the 
SPAD value practically did not vary by the years of the experiment. This refers to certain stability, which might be caused by the microenvironment in peat soil: a high stand of groundwater level in the harvested peat field and a high water absorption capacity of peat provide better and more stable humidity conditions in soil. This, in its turn, supports the plants to assimilate more water soluble nutrients from soil, which finally increases plant productivity.

In conclusion, it can be stated that environmental conditions exercised a considerable influence on biological processes of five-, six-year-old plants of half-highbush blueberry, at the same time, a genotype-based variation was observed. Cultivar 'Northblue' had a higher yield in mineral soil and 'Aino' had the highest yield in peat soil considering the average of two years. The peat soil condition in the harvested peat field provided a better supply of nutrients for blueberry bushes compared to mineral soil and this, in its turn, secured better growth and a higher yield of blueberry bushes.

\section{Acknowledgments}

This research was financed by Estonian Ministry of Agriculture, Estonian Science Foundation (Grants 6046 and 9363) for which we are sincerely grateful.

\section{References}

Ancu, I., lancu, M., Mladin, P. \& Ancu, S. 2010. The planting substrate effects on some growth characteristics of seven blueberry cultivars. Bulletin of University of Agricultural Sciences and Veterinary Medicine Cluj-Napoca Horticulture 67 (1): 91-95.

AOAC. 1990. Official Methods of Analysis 15th ed. Association of Official Analytical Chemists. Arlington, Virginia. $1230 \mathrm{p.}$

Barney, D.L. \& Hummer, K. E. Blueberry trials on Alaska's Kenai Peinsula first year report. 13 p. Cited 1 May 2011. Available on the Internet: http://www.swcgrl.ars.usda.gov/SP2UserFiles/Place/53581500/reduced\%20size\%20-\%20Blueberry\%20Trials\%20on\%20 the\%20Kenai\%20Peninsula\%20-\%20First\%20year\%20report.pdf.

Bläsing, D. 1989. Performance of highbush blueberries on sites previously used for agricultural crops. Acta Horticulturae 241 : 213-220.

Brown, J.M. 1976. Peat Temperature Regime of a Minnesota Bog and the Effect of Canopy Removal. Applied Ecology 13 (1): 89-194.

Delian, E., Bădulescu, L., Dobrescu, A., Săvulescu, E. \& Bădescu, C. 2010. Aspects regarding vegetative growing, reproductive development and minerals distribution in highbush blueberry leaves and fruits as affected by substrate composition. Journal of Horticulture, Forestry and Biotechnology 2: 334-341.

Eccher, T., Noé, N. \& Carotti, E. 2006. Field performance of Vaccinium corymbosum and V. ashei cultivars in Northern Italy. Acta Horticulturae 715: 247-254.

EMHI. 2006. Eesti Meteroloogia ja Hüdroloogia Instituut, sademed, ilmavaatlused. Homepage. Cited 11 July 2011. Available on the Internet: http://www.emhi.ee/ (in Estonian)

EMHI. 2007. Eesti Meteroloogia ja Hüdroloogia Instituut, sademed, ilmavaatlused. Cited 11 July 2011. Available on the Internet: http://www.emhi.ee/ (in Estonian)

Finn, C.E. \& Luby, J.J. 1986. Inheritance of fruit development interval and fruit size in blueberry progenies. Journal of the American Society for Horticultural Science 111: 784-788.

Grajkowski, J., Ochman, I. \& Muliński, Z. 2007. Firmness and Antioxidant Capacity of Highbush Blueberry (Vaccinium corymbosum L.) Grown on Three Types of Organic Bed. Vegetable Crops Research Bulletin 66: 155-159.

Haffner, K. \& Vestrheim, S. 1994. Kulturheidelbeeren - Eine neue Beerenproduktion in Norwegen. Erwerbsobstbau 36 (7): $184-$ 187. (in German)

Hall, I.V., Aalders, L.E. \& Townsend, L.R. 1964. Nitrogen uptake in blueberry fields. Canadian Journal of Plant Science 44: 30-36.

Korcak, R.F. 1988. Nutrition of blueberry and other calcifuges. Horticultural Reviews 10: 183-227.

Lehmushovi, A. 1998. Highbush blueberries in Finland. Forestry Studies 30:102-107.

Lehmushovi, A. 2000. Two Finnish highbush blueberries 'Aino' and 'Alvar'. Vuosikirja. Annual Reports 1997-1999. MTT Maatalouden tutkimuskeskus, Puutarhatuotanto Agricultural Research Centre of Finland, Horticulture, p. 25-26.

Lehmushovi, A. \& Hiirsalmi, H. 1995. Reliable blueberry cultivars for the Finnish climate conditions. Abstract Book. XIV EUCARPIA Congress "Adaption in plant breeding", University of Jyväskylä. p. 105.

Lehmushovi, A. \& Ylämäki, A. 1999. Pensasmustikkaakin on osattava viljellä. Puutarha \& Kauppa 11: 6-7. (in Finnish)

Lehmushovi, A., Ylämäki, A. \& Tahvonen, R. 2000. Pensasmustikkaa leikataan varoen. Puutarha \& Kauppa 35: 8-9. (in Finnish)

Li, Y., Xuedong, T., Lin, W. \& Zhang, Z. 2006. Effect of organic material on soil properties, plant growth, leaf photosynthesis, nutrient uptake and mycorrhizal infection of blueberries. Acta Horticulturae 715: 375-380.

Luby, J.J., Wildung, D.K., Stushnoff, C., Munson, S.T., Read, P.E. \& Hoover, E.E. 1986. 'Northblue', 'Northsky', and 'Northcounrty' Blueberries. HortScience 21: 1240-1242.

Lyrene, P.M. \& Balhgton, J.R. 1986. Wide hybridization in Vaccinium. HortScience 2: 152-57. 
Ochmian, I., Grajkowski J. \& Ostrowska, K. 2006. Growth and yield of American blueberry (Vaccinium corymbosum L.) of 'Patriot' cultivar grown on three types of organic bed. Electronic Journal of Polish Agricultural Universities, Horticulture, volume 9, issue 3. Cited 16 May 2011. Available on the Internet: http://www.ejpau.media.pl/volume9/issue3/abs-16.html.

Orru, M. 1995. Eesti turbasood. Eesti Geoloogiakeskus, Tallinn. 240 p. (in Estonian)

Paal, T., Starast, M., Noormets-Šanski, M., Vool, E., Tasa, T. \& Karp, K. 2011. Influence of liming and fertilization on lowbush blueberry in harvested peat field condition. Scientia Horticulturae 130 (1): 157-163.

Paasisalo, S., Kokko, H. \& Kärenlampi, S. 1994. Pensasmustikka marjantuotannossa: kasvatus- ja hoito-ohjeita. Kuopio: Liikekirjapaino Ky. 30 p. (in Finnish)

Prodorutti, D., Pertot, I., Giongo, L. \& Gessler,C. 2007. Highbush Blueberry: Cultivation, Protection, Breeding and Biotechnology. The European Journal of Plant Science and Biotechnology 1: 44-56.

Sanderson, K.R., Carter, M.R. \& Ivany, J.A. 1996. Effect of gypsum on yield and nutrient status of native blueberry. Canadian Journal of Plant Science 76: 361-366.

Spiers, J.M., 1986. Root distribution of 'Tifblue' rabbiteye blueberry as influenced by irrigation, incorporated peatmoss, and mulch. Journal of the American Society for Horticultural Science 111: 877-880.

Spiers, J.M. \& Braswell, J.H. 1992. Soil-applied sulphur affects elemental leaf content and growth of 'Tifblue 'rabbiteye blueberry. Journal of the American Society for Horticultural Science 230: 162-163.

Starast, M., Karp, K. \& Paal, T. 2002. The effect of using different mulches and growth substrates on half-highbush blueberry (Vaccinium corymbosum x V. angustifolium) cultivars 'Northblue' and 'Northcountry'. Acta Horticulturae 574: 281-286.

Starast, M., Karp, K., Vool, E. \& Moor, U. 2005. The cultivation of half-highbush blueberry under organic farming condition. Egyptian Journal of Agricultural Research 83 (1): 155-168.

Starast, M., Karp, K., Vool, E., Moor, U., Tõnutare, T. \& Paal, T. 2007a. Chemical composition and quality of cultivated and natural blueberry fruit in Estonia. Vegetable Crops Research Bulletin 66: 143-153.

Starast, M., Karp, K., Vool, E., Paal, T. \& Albert, T. 2007b. Effect of NPK fertilization and elemental sulphur on growth and yield of lowbush blueberry. Agricultural and Food Science 16: 34-45.

Strik, B. 2005. Blueberry: an expanding world berry crop. Chronica Horticulturae 45 (1): 7-12.

Šterne, D. \& Ābolinš, M. 2009. Evaluation of winter hardiness and productivity of five highbush blueberries cultivars in Latvia. Annual 15th International Scientific Conference Proceedings "Research for Rural Development 2009", Latvia University of Agriculture, Jelgava, 20-22 May 2009. p. 76-81.

Tahvonen, R., Hellstén, J., Ylämäki, A. \& Pulkkinen, J. 2008. Tarhamustikan ammattiviljely. Piikkiö: MTT puutarhatuotanto. 40 p. (in Finnish)

Trevett, M.F. 1972. A second approximation of leaf analysis standards for lowbush blueberries. Research in the life sciences. Maine Agricultural Experimental Station Bulletin 19 (5):15-16.

Vahejõe, K., Albert, T., Noormets, M., Karp, K., Paal, T., Starast, M. \& Värnik, R. 2010. Berry cultivation in cutover peatlands in Estonia: agricultural and economical aspects. Baltic Forestry 16 (2): 264-272.

Wildung, D.K. \& Sargent, K. 1989. The effect of snow depth on winter survival and productivity of Minnesota blueberries. Acta Horticulturae 241: 270-275.

Word reference base for soil resources 2006. IUSS Working Group WRB, 2nd edition, WordSoil Resourses Reports, No. 103, FAO, Rome. $145 \mathrm{p}$

Ylämäki, A. \& Tahvonen, R. 2004. Pensasmustikkalajikkeet sitkeän jalostuksen tulosta. Maataloustieteen Päivät 2004. Cited 16 May 2011. Available on the Internet: http://www.smts.fi/MTP\%20julkaisu\%202004/esi04/ti79.pdf.agronet.fi/maataloustieteellinenseura. (in Finnish)

Xie, Z.S. \& Wu, X.C. 2009. Studies on substrates for blueberry cultivation. Acta Horticulturae 810: 513-520. 